\title{
Long-Term Effects of Tenofovir on Liver Histopathology in Patients with Chronic Viral Hepatitis B Infection
}

\author{
Bengü TATAR' ${ }^{\mathbb{D}}$, Selma GÜL² (D), Şükran KÖSE ${ }^{1}$, Emel PALA ${ }^{3}$ (D)
}

Department of Infectious Diseases and Clinical Microbiology, 'University of Health Sciences, Izmir Tepecik Education and Research Hospital, IZMIR, TURKEY, ${ }^{2}$ Batman State Hospital, BATMAN, TURKEY, ${ }^{3}$ Department of Pathology, University of Health Sciences, Izmir Tepecik Education and Research Hospital, IZMIR, TURKEY

\section{ABSTRACT}

Objective: The aim of this study to evaluate histopathological improvement and virological, serological and biochemical response rates in patients with chronic hepatitis $\mathrm{B}(\mathrm{CHB})$ who were treated with tenofovir disoproxil fumarate (TDF).

Material and Method: A total of 91 nucleosid(t)e-naive CHB patients who received TDF were evaluated. Virological, serological and biochemical test results were assessed at baseline and every 12 weeks. Liver biopsy specimens were assessed according to the modified Ishak scoring.

Results: The study was conducted on 52 patients. The mean age was $40 \pm 10$ years and $40.4 \%$ were female. The mean follow-up period was $33 \pm 11$ months. HBsAg seroclearance occurred in none of the patients. The serum level of HBV-DNA became undetectable in $94.2 \%$ of the patients. Mean histological activity index at baseline and on-treatment were $8.2 \pm 2.3$ and $6.2 \pm 2.0$ and the mean fibrosis scores were $2.65 \pm 1.3$ and $2.33 \pm 1.1$, respectively.

Conclusion: We determined that TDF therapy provided remarkably good HBV DNA suppression and biochemical response rates, but low seroconversion. Improvement of liver necroinflammation was detected, but no significant change observed in fibrosis.

Key Words: Tenofovir, Hepatitis B, Histopathology

\section{INTRODUCTION}

Despite immunization programs for hepatitis B infection, chronic viral hepatitis $\mathrm{B}(\mathrm{CHB})$ infection remains an important public health problem. Worldwide, approximately 240 million persons have been infected with the hepatitis B virus. Each year 310.000- 340.000 people die due to cirrhosis and hepatocellular carcinoma $(1,2)$. Therefore, prevention of disease progression and prolonging survival constitute the primary goals of treatment. Today, advances in molecular biology techniques have provided a better understanding of the pathogenesis and natural history of the disease and new medications have been made available.

Resistance is an important problem in the long-term treatment of $\mathrm{CHB}$, and new nucleoside analogues are important treatment options because of low resistance rates. Tenofovir disoproxil fumarate (TDF) is the acyclic phosphonatediesther analog of adenosine monophosphate $(3,4)$ and its high genetic barrier against the mutations in DNA polymerase suggests that less problem will be encountered in terms of resistance (5). Nevertheless, both the virological and histopathological long-term outcomes of TDF therapy in $\mathrm{CHB}$ patients are unclear.
Despite advances in noninvasive diagnostic methods, histopathological examination of the liver biopsy remain the gold standard in diagnosing, identifying the stage, and monitoring the course of the disease. Although demonstration of virological, serological and biochemical healing is an important issue in evaluating therapy response, demonstration of histological improvement provides important information on the prognosis.

In this study, we aimed to evaluate histopathological improvement as well as virological, serological and biochemical response rates in the cases being followed for $\mathrm{CHB}$ and receiving TDF therapy.

\section{MATERIAL and METHOD}

\section{Patient Selection}

A total of 91 nucleoside-naive patients over the age of 17 years, who have been followed in our clinic for CHB and received TDF therapy at a dose of $245 \mathrm{mg}$ /day for at least 12 months, were included in the study. According to the diagnostic criteria of the American Association for the Study of Liver Diseases (AASLD) defined for CHB, cases in which $\mathrm{HBsAg}$-positivity has persisted for more than

Correspondence: Bengu TATAR

University of Health Sciences, Izmir Tepecik Education and Research Hospital, Department of Infectious Diseases and Clinical Microbiology, IZMIR, TURKEY E-mail: b.gtatar@hotmail.com Phone: +90 2324696969 
six months were defined as chronic hepatitis B. According to the Health Application Statement being applied in our country, TDF therapy was administered at a dose of 245 $\mathrm{mg} /$ day to those with HBV-DNA $>20000 \mathrm{IU} / \mathrm{ml}$ for positive $\mathrm{HBeAg}$ and $>2000 \mathrm{IU} / \mathrm{ml}$ for negative HBeAg patients, with the serum alanine aminotransferase (ALT) level higher than twice the normal value, and in which the liver biopsy showed chronic hepatic disease.

\section{Exclusion Criteria}

Patients were excluded from the study if they had coinfection with hepatitis C, hepatitis D or HIV or any other liver disease such as autoimmune hepatitis, hemochromatosis, alcoholic liver disease, drug-induced hepatitis, decompensated cirrhosis or Wilson's disease, or if they had no recorded HBV DNA and serum ALT levels at baseline and did not receive regular checks during the follow-up visits.

\section{Laboratory Values}

The patients were tested in terms of HBV-DNA, Anti-HCV, Anti-HDV, Anti HIV, coagulation tests, ALT, AST, ALP, GGT, AFP, and autoantibodies at baseline. HBsAg, Anti$\mathrm{HBcIgG}, \mathrm{HBeAg}$, Anti-HBe, Anti-HCV, and Anti-HDV were studied by ELISA (Liaison, Diasorin, Italy). The HBVDNA level was studied using the real-time polymerase chain reaction (PCR) (COBASAmpli Prep/ COBAS, TaqMan; lower limit of quantification, 20 UL per mililiter), and lamivudin resistance was studied by Inno-lipa HBVDR V2 (LIPA; Innogetetics N.V.; Gent; Belgium). Virological, serological and biochemical tests were performed every 12 weeks.

Liver biopsy materials were evaluated according to the modified ISHAK scoring. Stages of fibrosis were grouped as mild (1-2), moderate (3-4) and severe (5-6) and the necroinflammation degree was grouped as mild (1-6), moderate (7-12) and severe (13-18). Biopsy materials taken before treatment were reevaluated by a single pathologist.

\section{Efficacy Endpoints}

Primary efficacy endpoint was histopathological improvement ( $\geq 2$ points improvement in necroinflammation and $\geq 1$ point improvement in fibrosis). Secondary efficacy endpoints were the virological and biochemical response, $\mathrm{HBeAg}$ seroclearance, $\mathrm{HBeAg}$ seroconversion, and loss of $\mathrm{HBsAg}$.

\section{Statistical Analysis}

All the statistical analyses were performed with the SPSS 15.0 Windows package program. Mean $( \pm$ SD) and median $\left[25^{\text {th }}-75^{\text {th }}\right.$ percentile] values were calculated. A $\mathrm{p}$ value less than 0.05 was considered statistically significant. The
"Shapiro-Wilk" test was used to assess normal distribution. For normally distributed numerical variables, Student's t-test was used to compare values at baseline and ontreatment. For numerical variables that were not normally distributed, the two groups were compared using the Wilcoxon test. The Mac-Nemar-Bowker test for percentage of $\mathrm{HBeAg}$-positivity was used to compare results between baseline and on-treatment.

\section{RESULTS}

Ninety-one patients who were followed with the diagnosis of CHB and were receiving $245 \mathrm{mg}$ /day TDF were included in the study. Of these patients, 18 who declined control biopsy, 10 who were not receiving treatment regularly and 11 for whom initial biopsy specimens were not available were excluded and the study was conducted on 52 patients. The mean age of the patients was 39.9 \pm 9.8 (18-70) years and $31(59.6 \%)$ were male. The mean follow-up period was $33.12 \pm 11.24$ months (Table I). All patients were genotype D. Twenty two (42.3\%) of the patients were $\mathrm{HBeAg}$ positive and $\mathrm{HBeAg}$ seroclearance developed in three patients and seroconversion developed in one patient. No patient lost HBsAg. In 49 (94.2\%) of the patients, the serum level of HBV-DNA became negative on-treatment ( $<20 \mathrm{IU} / \mathrm{Ml})$.

The median $\left[25^{\text {th }}-75^{\text {th }}\right.$ percentile $]$ HBV-DNA levels at baseline and on-treatment were $1.0 \times 10^{8} \mathrm{IU} / \mathrm{Ml}\left[3.4 \times 10^{6}\right.$ $\left.1.0 \times 10^{8}\right]$ and $2.0 \times 10^{1} \mathrm{IU} / \mathrm{Ml}\left[1.0-2.0 \times 10^{1}\right]$ respectively $(\mathrm{p}<0.001)$. The median ALT level was $87 \mathrm{U} / \mathrm{L}$ [59-126] at baseline (ALT level was 2 times higher than the normal value in $65.4 \%$ of the patients; $>35 \mathrm{U} / \mathrm{L}$ in females and $>45 \mathrm{U} / \mathrm{L}$

Table I: Baseline clinical characteristics of the patients

Patients ( $\mathrm{n}=52)$

Median $\left[25^{\text {th }}-75^{\text {th }}\right.$

percentile] / Mean \pm Std.

Deviation

\begin{tabular}{lc}
\hline Age (year) & $39.9 \pm 9.8$ \\
\hline Male n, (\%) & $31(59.6)$ \\
\hline HBeAg-positive n, (\%) & $22(42.3)$ \\
\hline Serum HBV DNA (IU/ml) & $9.5 \times 10^{7}\left[3.3 \times 10^{7}-1.0 \times 10^{8}\right]$ \\
\hline $\begin{array}{l}\text { Histological activity index } \\
\text { (Ishak) }\end{array}$ & $8.0[7.0-9.5]$ \\
\hline Fibrosis (Ishak) & $2.50[4-8]$ \\
\hline ALT (U/L) & $85.5[59-126]$ \\
\hline AST (U/L ) & $59.0[40-78]$ \\
\hline $\begin{array}{l}\text { Duration of TDF } \\
\text { treatment (month) }\end{array}$ & $33.12 \pm 11.24$ \\
\hline
\end{tabular}


in males) and the median ALT level regressed to $25 \mathrm{U} / \mathrm{L}$ [22-32] on-treatment $(\mathrm{p}<0.001)$. The median histological activity indexes at baseline and on-treatment were 8 [7-10] and $6[8-10]$ respectively $(\mathrm{p}<0.001)$ and the median fibrosis scores were $3[2-3]$ and $2[1-3]$ respectively $(\mathrm{p}=0.17) ; 15$ (28.9\%) of 52 patients had a fibrosis score $\geq 4$ at baseline (Table II). The mean virological and biochemical responses were 12.8 months and 4.8 months respectively.
On-treatment, $59.6 \%$ of the patients showed $\geq 2$ points improvement in histological activity index and $57.7 \%$ of the patients showed $\geq 1$ point improvement in fibrosis (Table III), (Figure 1). Histological changes and the degree of portal inflammation between baseline and on-treatment were given in Figure 2 and 3.

Table II: Baseline and on-treatment laboratory and histological results of the study patients

\begin{tabular}{lccc}
\hline & Baseline & On- treatment & p \\
& Median $\left[25^{\text {th }}-75^{\text {th }}\right.$ percentile $]$ & Median $\left[25^{\text {th }}-75^{\text {th }}\right.$ percentile $]$ & $2.0 \times 10^{1}\left[1.0-2.0 \times 10^{1}\right]$ \\
\hline Serum HBV DNA (IU/ml) & $1.0 \times 10^{8}\left[3.4 \times 10^{6}-1.0 \times 10^{8}\right]$ & 36.5 & $<0.001$ \\
\hline HBeAg-positive, $\%$ & 42.3 & $25[22-32]$ & 0.25 \\
\hline ALT (U/L) & $87[59-126]$ & $6[8-10]$ & $<0.001$ \\
\hline Histological activity index (Ishak) & $8[7-10]$ & $2[1-3]$ & $<0.001$ \\
\hline Fibrosis (Ishak) & $3[2-3]$ & & 0.17 \\
\hline
\end{tabular}

Table III: Distribution of baseline and on-treatment hepatic activity index and fibrosis in study patients

\begin{tabular}{lcc}
\hline & $\begin{array}{c}\text { Baseline } \\
(\mathbf{n}=52)\end{array}$ & $\begin{array}{c}3^{\text {rd }} \text { year of } \\
\text { treatment }(\mathbf{n = 5 2})\end{array}$ \\
\hline Hepatic Activity Index & & \\
\hline $1-6 \mathrm{n},(\%)$ & $13(25)$ & $28(54)$ \\
\hline $7-12 \mathrm{n},(\%)$ & $37(71)$ & $24(46)$ \\
\hline $13-18 \mathrm{n},(\%)$ & $2(4)$ & $0(0)$ \\
\hline Fibrosis & & \\
\hline $1-2 \mathrm{n},(\%)$ & $26(50.0)$ & $32(61.5)$ \\
\hline $3-4 \mathrm{n},(\%)$ & $21(40.4)$ & $18(34.6)$ \\
\hline $5-6 \mathrm{n},(\%)$ & $5(9.6)$ & $2(3.8)$ \\
\hline
\end{tabular}

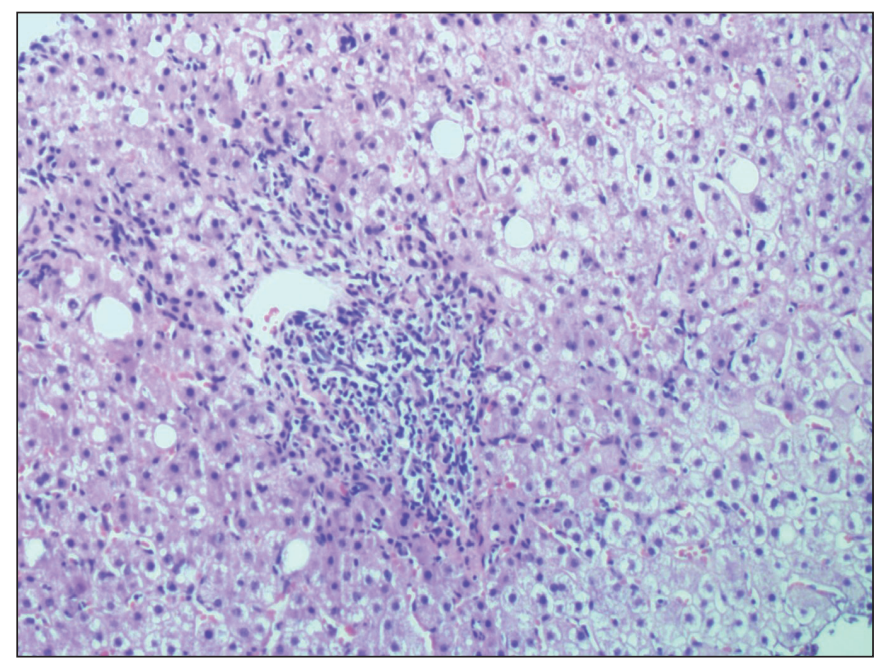

Figure 2: Liver biopsy showing portal inflammation (grade 2) at baseline (H\&E; x200).

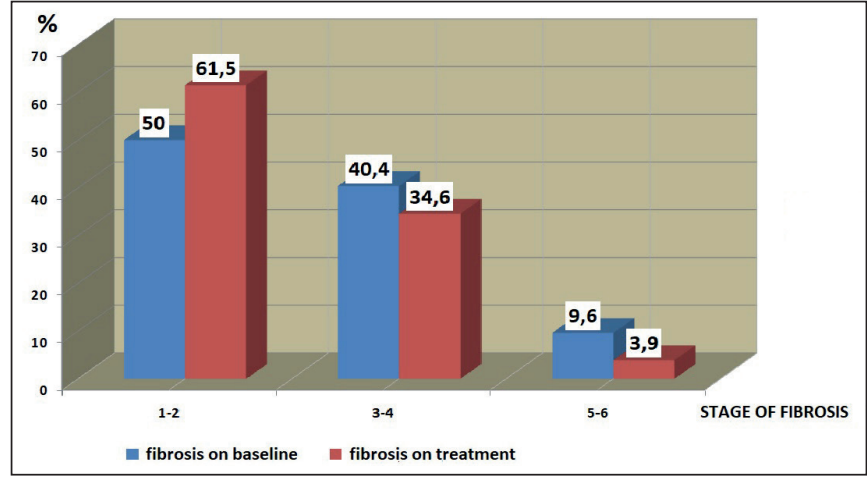

Figure 1: Distribution of the patients at baseline and on-treatment according to stage of fibrosis.

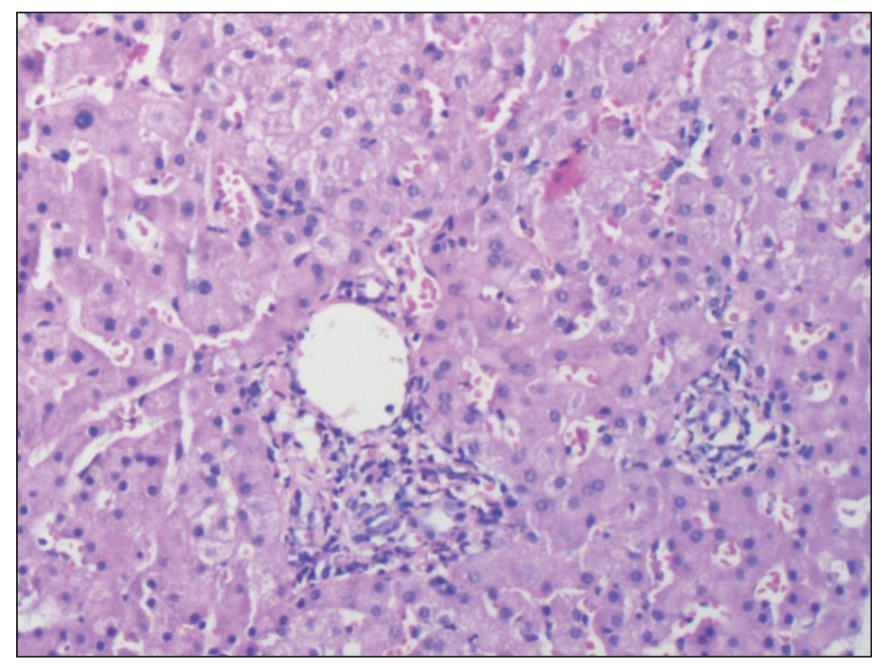

Figure 3: Liver biopsy showing portal inflammation (grade 1) ontreatment (H\&E; x200). 


\section{DISCUSSION}

In the present study, we determined that TDF therapy provided remarkably good HBV DNA suppression and biochemical response rates, but low seroconversion.

The management of $\mathrm{CHB}$ treatment has improved in the last decade along with the availability of new nucleoside analogues. These drugs are superior to interferon therapy since they are well-tolerated, are highly potent and have a low side effect profile. However, long-term therapy creates an antiviral resistance problem. TDF is one of the first choices in CHB treatment due to its high genetic barrier and high potency $(6,7)$. Marcellin et al. conducted a randomized controlled study to compare TDF and adefovir therapies in CHB patients and found TDF to be superior to adefovir in terms of both histological and virological response. In these patients, the virological response rate was $76 \%$ in HbeAg-positive patients in the $1^{\text {st }}$ year of treatment and it was found to be $93 \%$ in HbeAg-negative patients (4). Lampertico et al. carried out a multicenter study in 19 European countries including 302 patients and obtained a virological response in the great majority of patients in the $2^{\text {nd }}$ year of treatment. In that study, it was conspicuous that approximately half of the patients had a comorbid condition and $1 / 3$ had cirrhosis (8). Similarly, the serum HBV-DNA level has been suppressed to $<20 \mathrm{IU} / \mathrm{Ml}$ on the $3^{\text {rd }}$ year of treatment (longer-term result as compared to the other studies) in approximately $95 \%$ of the patients and mean virologic response time was approximately 1 year, as seen in the present study as well. Similar to the previous studies, the $\mathrm{HBeAg}$ seroconversion rate was low in the present study (9). This might be associated with low rate of baseline $\mathrm{HBeAg}$ positivity, relatively short follow-up period, and the genotype D.

In the present study, we determined histological improvement with TDF therapy in approximately $60 \%$ of the patients but no significant improvement was detected in fibrosis.

In the literature, the number of studies investigating effect of TDF therapy on histological improvement is quite limited. In the study conducted by Marcellin et al., in which TDF and adefovir therapies were compared in CHB patients and histological evaluation was based on Knodell scoring, histological improvement was determined in approximately $2 / 3$ of the patients receiving TDF therapy (4). These results were similar to those of the present study. The other important issue was the absence of side effects in all of our patients. This confirms the safety of the drug.
The present study has some limitations. The limited number of patients and absence of a control group are the major limitations. In addition, since the viral genotype was $\mathrm{D}$ in all of the patients, the chance to evaluate the response of other genotypes to TDF therapy was lacking.

In conclusion, TDF is a quite efficient therapy in $\mathrm{CHB}$ patients in terms of both histological improvement and virological response. Large-scale studies and longer-term results are needed to determine whether there will be problems in terms of efficacy of and resistance against TDF therapy.

\section{CONFLICT of INTEREST}

The authors declare no conflict of interest.

\section{FUNDING}

None

\section{REFERENCES}

1. Stasi C, Silvestri C, Voller F, Cipriani F. The epidemiological changes of HCV and HBV infections in the era of new antiviral therapies and the anti-HBV vaccine. J Infect Public Health. 2016;9:389-95.

2. Lozano R, Naghavi M, Foreman K, Lim S, Shibuya K, Aboyans V, Abraham J, Adair T, et al. Global and regional mortality from 235 causes of death for 20 age groups in 1990 and 2010: A systematic analysis for the Global Burden of Disease Study 2010. Lancet. 2012;380:2095-128.

3. Woo G, Tomlinson G, Nishikawa Y, Kowgier M, Sherman M, Wong DK, Pham B, Ungar WJ, Einarson TR, Heathcote EJ, Krahn M. Tenofovir and entecavir are the most effective antiviral agents for chronic hepatitis B: A systematic review and Bayesian metaanalyses. Gastroenterology. 2010;139:1218-29.

4. Marcellin P, Heathcote EJ, Buti M, Gane E, de Man RA, Krastev Z, Germanidis G, Lee SS, Flisiak R, Kaita K, Manns M, Kotzev I, Tchernev K, Buggisch P, Weilert F, Kurdas OO, Shiffman ML, Trinh H, Washington MK, Sorbel J, Anderson J, Snow-Lampart A, Mondou E, Quinn J, Rousseau F. Tenofovir disoproxil fumarate versus adefovirdipivoxil for chronic hepatitis B. N Engl J Med. 2008;359:2442-55.

5. van Bömmel F, Wünsche T, Schürmann $\mathrm{D}$, Berg T. Tenofovir treatment in patients with lamivudine-resistant hepatitis B mutants strongly affects viral replication. Hepatology. 2002;36:507-8.

6. Snow-Lampart A, Chappell B, Curtis M, Zhu Y, Myrick F, Schawalder J, Kitrinos K, Svarovskaia ES, Miller MD, Sorbel J, Heathcote J, Marcellin P, Borroto-Esoda K. No resistance to tenofovir disoproxil fumarate detected after up to 144 weeks of therapy in patients monoinfected with chronic hepatitis B virus. Hepatology. 2011;53:763-73. 
7. Heathcote EJ, Marcellin P, Buti M, Gane E, De Man RA, Krastev Z, Germanidis G, Lee SS, Flisiak R, Kaita K, Manns M, Kotzev I, Tchernev K, Buggisch P, Weilert F, Kurdas OO, Shiffman ML, Trinh H, Gurel S, Snow-Lampart A, Borroto-Esoda K, Mondou E, Anderson J, Sorbel J, Rousseau F. Three-year efficacy and safety of tenofovir disoproxil fumarate treatment for chronic hepatitis B. Gastroenterology. 2011;140:132-43.

8. Lampertico P, Soffredini R, Viganò M, Yurdaydin C, Idilman R, Papatheodoridis G, Margariti K, Buti M, Esteban R, Zaltron S, Vavassori A, Carosi G, Minola E, Vinci M, et al. 2 year effectiveness and safety of tenofovir in 302 NUC-naïve patients with chronic hepatitis B: A multicenter European study in clinical practice. Hepatology. 2011;54(Suppl 1): Abstract 1433.
9. Carey I, Nguyen DorothyJoe H, Al-Freah M, Knighton S, Bruce M, Suddle A, Harrison PM, Agarwal K. De-novo antiviral therapy with nucleos(t)ide analogues in real-life patients with chronic hepatitis B infection: Comparison of virological responses between lamivudine+adefovir, entecavir vs. tenofovir therapy. Gut. 2011;60 (Suppl 2). 